\title{
PENGEMBANGAN INSTRUMEN ASESMEN KOMPREHENSIF BERBASIS KOMPETENSI PADA MATA PELAJARAN IPA/BIOLOGI
}

\author{
Anang Triyoso ${ }^{1)}$ \\ H. Muslimin Ibrahim ${ }^{2)}$ \\ Raharjo ${ }^{2)}$ \\ 1)Mahasiswa Pascasarjana Prodi Pendidikan Sains Universitas Negeri Surabaya \\ 2)Dosen Pascasarjana Prodi Pendidikan Sains Universitas Negeri Surabaya \\ e-mail: atriyoso@yahoo.com
}

\begin{abstract}
This research aims was to develop a competency-based assessment instruments in subject of Science/Biology. This research was carried out through the development of the following 4-D design models of Thiagarajan (1974) and then continued the implementation the classroom using One Shot Case Study Design. The data were obtained as follows: the results of the validation instruments decent role in the category; legibility of instruments indicates that the content, appearance, difficulty sentences and interesting pictures and easy to understand students; enforceability of good category; effectiveness of the instrument showed that cognitive assessment to have a reliability tes objective 0.39, the level of difficulty of items were easily as many as 11 items (36.7\%), medium as many as 16 items (53.3\%), and difficult as many as 3 items (10\%), sensitive items as many as 27 items (90\%) and less sensitive as many as 3 items (10\%), while the essay test has a reliability of 0.45 , an easy difficulty level items as many as 2 items (20\%), medium as many as 4 items (40\%), and difficult as many as 4 items (40\%), sensitive items as many as 6 items (60\%) and less sensitive as many as 4 items (40\%); assessment of the affective domain has a reliability 0.81; assessment of psychomotor domains I has a reliability of 0.52 and psychomotor II has a reliability of 0.62 . Student field constraints are not accustomed to using competency-based assessment instrument. Based on the analysis of data, it can be concluded that a Competency-Based Assessment Instruments in subject of Science/Biology that have been developed are valid, practical, and effective.
\end{abstract}

Key words: Comprehensive Assessment, Competency, Development Research

\begin{abstract}
Abstrak: Penelitian ini bertujuan untuk mengembangkan instrumen asesmen komprehensif berbasis kompetensi pada mata pelajaran IPA/Biologi. Penelitian ini dilaksanakan melalui pengembangan instrumen mengikuti rancangan 4-D model dari Thiagarajan (1974) kemudian dilanjutkan implementasi di kelas menggunakan rancangan One Shot Case Study. Data hasil penelitian yang diperoleh sebagai berikut: hasil validasi instrumen dalam kategori layak; keterbacaan instrumen menunjukkan bahwa isi, penampilan, kesulitan kalimat dan gambar menarik dan mudah dipahami siswa; keterlaksanaan instrumen berkategori sangat baik; keefektifan instrumen menunjukkan bahwa asesmen ranah kognitif untuk tes objektif memiliki reliabilitas 0,39, tingkat kesukaran butir soal mudah sebanyak 11 butir soal (36,7\%), sedang sebanyak 16 butir soal (53,3\%), dan sukar sebanyak 3 butir soal (10\%), butir soal sensitif sebanyak 27 butir soal (90\%) dan kurang sensitif sebanyak 3 butir soal (10\%), sedangkan tes uraian memiliki reliabilitas 0,45, tingkat kesukaran butir soal mudah sebanyak 2 butir soal (20\%), sedang sebanyak 4 butir soal (40\%), dan sukar sebanyak 4 butir soal (40\%), butir soal sensitif sebanyak 6 butir soal (60\%) dan kurang sensitif sebanyak 4 butir soal (40\%); asesmen ranah afektif memiliki reliabilitas 0,81; asesmen ranah psikomotor I memiliki reliabilitas 0,52 dan psikomotor II memiliki reliabilitas 0,62. Kendala lapangan adalah siswa belum terbiasa menggunakan instrumen asesmen komprehensif berbasis kompetensi. Berdasarkan hasil analisis data, dapat disimpulkan bahwa instrumen asesmen komprehensif berbasis kompetensi pada mata pelajaran IPA/Biologi yang dikembangkan valid, praktis, dan efektif.
\end{abstract}

Kata-kata Kunci: Asesmen Komprehensif, Kompetensi, Penelitian Pengembangan

\section{PENDAHULUAN}

Pembelajaran sebagai suatu proses mengandung tiga unsur yang memiliki hubungan timbal balik, yakni tujuan pembelajaran, proses pembelajaran, dan penilaian (asesmen) pembelajaran (Sudjana, 2012). Sebagai salah satu unsur, asesmen pembelajaran dimaksudkan untuk mengetahui sejauhmana ketercapaian kompetensi siswa dan keefektifan proses pembelajaran yang ditujukan dalam mencapai tujuan pembelajaran.

Asesmen pembelajaran adalah menilai sejauhmana peserta didik mengkonstruksi pengetahuan. Hal ini sejalan dengan konstruktivisme belajar yang memandang bahwa pengetahuan dibangun oleh individu melalui pengalaman (Slavin, 2009). Asesmen menurut pembelajaran konstruktivisme memiliki ciri-ciri yakni a) dilakukan terintegrasi dengan pembelajaran; b) mengukur proses dan produk pembelajaran; c) dilakukan dengan berbagai teknik sehingga dapat mengukur segala aspek perkembangan berpikir peserta didik; dan d) bermanfaat untuk memperbaiki proses pembelajaran (Suwono, 2011). 
Pembelajaran berbasis kompetensi menekankan pada konsep pencapaian kompetensi maka jenis penilaian juga harus disesuaikan dengan kekhasan masing-masing kompetensi (Depdiknas, 2008a).

Hasil pembelajaran IPA di Indonesia bisa dicermati dari fakta hasil literasi IPA anak-anak Indonesia yang dipublikasikan oleh PISA dan TIMSS, dimana hasil menunjukkan bahwa pendidikan IPA di Indonesia belum memuaskan, karena siswa Indonesia rata-rata baru mampu mengingat pengetahuan berdasarkan fakta sederhana dan mendasar, sedangkan penguasaan keterampilan memecahkan masalah dalam kehidupan sehari-hari masih rendah. Literasi IPA tidak hanya sekedar memahami faktafakta, menghafal istilah, dan prinsip sains.

Pembelajaran IPA yang membantu siswa menjadi menguasai produk, proses, dan sikap tidak cukup hanya mengajarkan istilah dan prinsip saja, tetapi juga mengajak siswa melakukan penyelidikan ilmiah serta mengkomunikasikan hasilnya.

Kenyataannya dalam melaksanakan penilaian hasil belajar IPA di sekolah terdapat kecenderungan dari para pendidik untuk mengutamakan penggunaan tes (paper and pencil test) sebagai satu-satunya alat ukur yang terpenting dalam proses pendidikan (Hairida, 2011).

Kondisi seperti ini dalam jangka waktu yang lama mendorong penggunaan tes secara berlebihan untuk mengukur semua tujuan pembelajaran yang telah direncanakan. Padahal tes itu sendiri memiliki keterbatasan, karena tidak mampu mengukur kemampuan peserta didik yang sebenarnya dan hanya terfokus pada beberapa aspek saja. Tes ini juga tidak memberi kesempatan kepada peserta didik untuk menunjukkan kemampuan atau potensi masingmasing. Ini terbukti berakibat sangat fatal, yaitu guru dalam mengelola pembelajaran hanya berorientasi pada bagaimana prestasi peserta didiknya akan dinilai nanti, sehingga guru tidak merasa perlu untuk mengikuti berbagai inovasi pembelajaran dan lebih baik mengajak peserta didiknya berlatih menjawab berbagai bentuk soal.

Menurut Ibrahim (2005), hasil penilaian yang sepihak menggunakan paper and pencil test ini tentu belum cukup untuk membuat keputusan tentang peserta didik. Karena itu pelaksanaan penilaian di persekolahan harus mencakup berbagai jenis alat ukur. Hal ini disebabkan semua alat ukur memiliki peranan tersendiri dan saling mendukung dalam pengukuran hasil belajar.

Salah satu cara yang dapat dilakukan untuk mewujudkan penilaian kelas yaitu dengan mengkombinasikan hasil belajar (produk) dan penilaian proses yang mencakup penilaian ranah kognitif, afektif dan psikomotor. Penilaian terpadu yang komprehensif dan seimbang antara proses dan hasil dalam kurikulum tersebut dilaksanakan dalam kerangka penilaian kelas. Jadi dibutuhkan pedoman penilaian yang mampu mengukur perkembangan pencapaian kompetensi peserta didik secara komprehensif pada ketiga ranah tujuan pembelajaran tersebut.

Wiggins (1993) menyatakan bahwa sebuah asesmen adalah komprehensif, beragam analisis kinerja, yang harus berbasis keputusan dan personal.

Munculnya tuntutan adanya suatu model asesmen komprehensif adalah karena pertama selama ini modelmodel penilaian yang ada belum mampu menggali informasi secara menyeluruh pada obyek penilaian. Selama ini baru berdasarkan skor dari penilaian produk (benda kerja), belum mampu menggali aspek afektif (sikap dan perilaku) dan keterampilan proses. Kedua, adanya tuntutan bahwa penilaian mestinya menjadi bagian integral dari suatu proses pembelajaran, melalui umpan balik terhadap siswa selama proses pembelajaran praktik berlangsung.

Berdasarkan uraian tersebut, dapat disimpulkan perlunya suatu penelitian tentang pengembangan instrumen asesmen komprehensif berbasis kompetensi dalam mata pelajaran IPA/Biologi. Dengan harapan instrumen asesmen ini nantinya dapat digunakan secara operasional di sekolah.

\section{METODE PENELITIAN}

Penelitian ini termasuk penelitian pengembangan (developmental research), karena mengembangkan instrumen asesmen komprehensif berbasis kompetensi pada mata pelajaran IPA/Biologi. Model yang digunakan dalam pengembangan instrumen asesmen komprehensif berbasis kompetensi adalah model 4 D (Four D Model) yang dikembangkan oleh Thiagarajan, et.al. (1974).

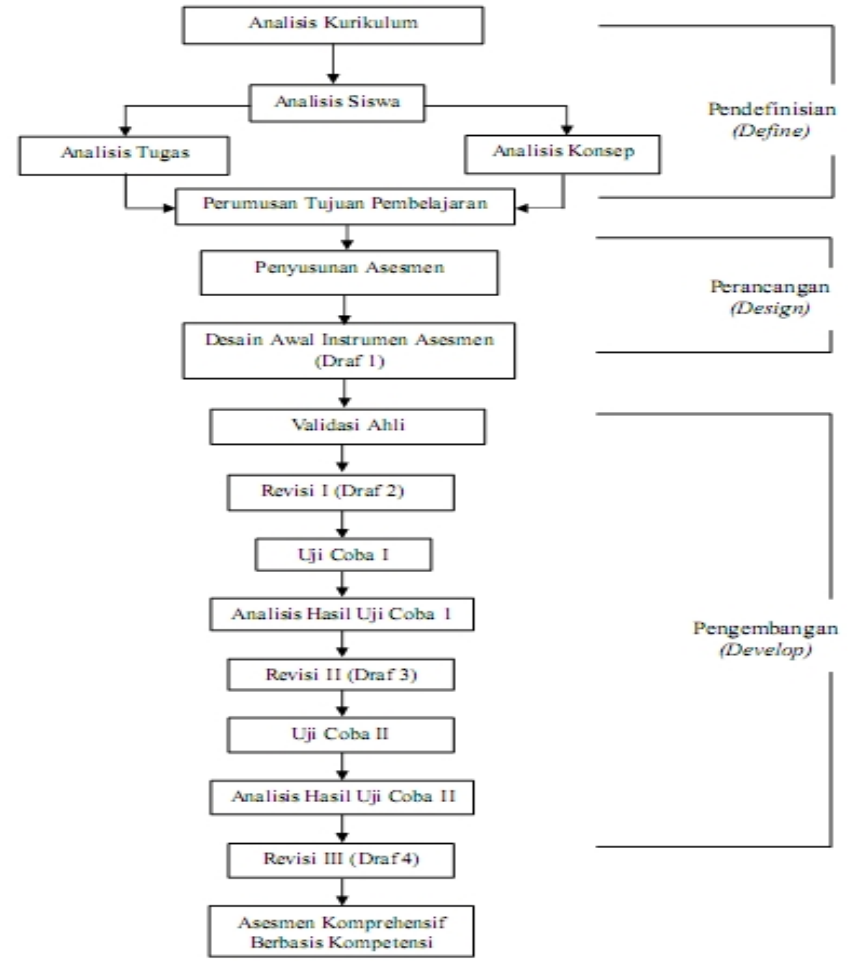


Gambar 1. Diagram Alir Rancangan Pengembangan Instrumen Asesmen (Diadaptasi dari Thiagarajan, et.al. 1974.

Ujicoba penelitian ini dilakukan pada 34 siswa kelas VIII A SMP Negeri 1 Menganti Gresik dengan pemilihan subjek penelitian ini dilakukan secara random sampling.

Desain penelitian pada ujicoba mengimplementasikan rancangan eksperimen model one shotcase study, karena hanya menggunakan satu kelas eksperimen tanpa adanya pembanding dan juga tanpa tes awal.

Instrumen asesmen komprehensif berbasis kompetensi tersebut kemudian divalidasi oleh dua pakar pendidikan. Teknik pengumpulan data pada penelitian ini menggunakan teknik validasi, tes, observasi, angket, dan wawancara. Materi yang dikembangkan dalam instrumen asesmen komprehensif berbasis kompetensi adalah 1) asam, basa, dan garam, 2) gejala alam, dan 3) keanekaragaman makhluk hidup. Hasil pengembangan instrumen asesmen kompehensif berbasis kompetensi adalah validitas instrumen, kepraktisan instrumen, dan karakteristik instrumen.

\section{HASIL DAN PEMBAHASAN}

\section{a. Pengembangan Instrumen Asesmen Komprehensif}

Dalam penelitian ini, instrument asesmen komprehensif berbasis kompetensi digunakan untuk mengukur pencapaian beberapa kompetensi dasar selama 1 semester yaitu pada semester gasal Kelas VII SMP, dimana terdiri dari 7 kompetensi dasar. Kompetensi dasar tersebut diuraikan menjadi 36 indikator dengan rincian 23 indikator produk ilmiah, 10 indikator proses ilmiah, 1 indikator afektif dan 2 indikator psikomotor. Selanjutnya diuraikan lagi menjadi 23 tujuan pembelajaran produk ilmiah, 10 tujuan pembelajaran proses ilmiah, 1 tujuan pembelajaran afektif dan 2 tujuan pembelajaran psikomotor.

Penyusunan lembar asesmen berdasarkan tujuan pembelajaran yang terdiri atas tiga macam lembar asesmen, yaitu: lembar asesmen ranah kognitif, lembar asesmen ranah afektif, dan lembar asesmen ranah kognitif. Lembar asesmen ranah kognitif diujikan dalam 2 bentuk yaitu tes objektif (produk ilmiah) dan tes uraian (proses ilmiah). Lembar asesmen ranah afektif diujikan dalam bentuk angket, terdiri dari lima aspek afektif yaitu 1) kesesuaian sikap, 2) kesesuaian minat, 3) kesesuaian konsep diri, 4) kesesuaian nilai, dan 5) kesesuaian moral. Sedangkan lembar asesmen ranah psikomotor yang diujikan dengan meminta siswa : 1) memeriksa sifat asam basa larutan menggunakan indikator kertas lakmus dan indikator alami, dan 2) menggunakan mikroskop dengan benar.

\section{b. Validasi Instrumen Asesmen Komprehensif}

Validasi instrumen asesmen komprehensif berbasis kompetensi meliputi validasi asesmen kognitif, validasi asesmen afektif, dan validasi asesmen psikomotor oleh pakar. Hasil analisis penilaian instrumen asesmen komprehensif berbasis kompetensi tersebut ditunjukkan pada Tabel 1 berikut ini:

Tabel 1. Hasil Validasi Instrumen Asesmen Komprehensif Berbasis Kompetensi

\begin{tabular}{|c|c|c|c|c|c|}
\hline No & $\begin{array}{c}\text { Jenis } \\
\text { Instrumen }\end{array}$ & $\begin{array}{c}\text { Aspek } \\
\text { Penilaian }\end{array}$ & $\begin{array}{l}\text { Nilai } \\
\text { Rata- } \\
\text { Rata }\end{array}$ & $\begin{array}{l}\text { Kate- } \\
\text { gori }\end{array}$ & $\begin{array}{l}\text { Relia- } \\
\text { bilitas }\end{array}$ \\
\hline \multirow{4}{*}{1} & \multirow{4}{*}{$\begin{array}{l}\text { Lembar } \\
\text { asesmen } \\
\text { kognitif }\end{array}$} & Validasi isi & 4,36 & Layak & $90 \%$ \\
\hline & & $\begin{array}{l}\text { Validasi } \\
\text { konstruksi }\end{array}$ & 4,39 & Layak & $88 \%$ \\
\hline & & Validasi bahasa & 4,38 & Layak & $92 \%$ \\
\hline & & Nilai Rata-rata & 4,38 & Layak & $90 \%$ \\
\hline \multirow{4}{*}{2} & \multirow{4}{*}{$\begin{array}{l}\text { Lembar } \\
\text { asesmen } \\
\text { psikomo- } \\
\text { tor }\end{array}$} & Validasi isi & 4,38 & Layak & $92 \%$ \\
\hline & & $\begin{array}{l}\text { Validasi } \\
\text { konstruksi }\end{array}$ & 4,00 & Layak & $92 \%$ \\
\hline & & Validasi bahasa & 4,50 & Layak & $89 \%$ \\
\hline & & Nilai Rata-rata & 4,29 & Layak & $91 \%$ \\
\hline \multirow[b]{2}{*}{3} & \multirow{2}{*}{$\begin{array}{l}\text { Lembar } \\
\text { asesmen } \\
\text { afektif }\end{array}$} & Validasi & 4,17 & Layak & $92 \%$ \\
\hline & & Nilai Rata-rata & 4,17 & Layak & $92 \%$ \\
\hline
\end{tabular}

Berdasarkan tabel tersebut bahwa hasil validasi instrument asesmen komprehensif oleh dua pakar pendidikan meliputi lembar asesmen ranah kognitif, lembar asesmen ranah psikomotor, dan lembar asesmen ranah afektif berkategori layak. Hasil tersebut menunjukkan bahwa instrumen asesmen komprehensif layak digunakan sebagai alat ukur pencapaian kompetensi dasar, reliabel dan memenuhi kriteria untuk diujicobakan kepada siswa.

Menurut pendapat Surapranata (2005) dan Arikunto (2013), yang menyatakan bahwa sebuah tes dikatakan memiliki validitas isi apabila mengukur sesuai dengan domain dan tujuan khusus tertentu yang sama dengan isi pelajaran yang telah diberikan di kelas. Secara kongkret dikemukakan oleh Ibrahim (2005), sejauhmana soal-soal tes itu telah representatif untuk mengukur isi pelajaran.

Sesuai pendapat Surapranata (2005), Ratumanan dan Laurens (2011), dan Arikunto (1013) bahwa sebuah tes dikatakan memiliki validitas konstruksi apabila soalsoalnya mengukur setiap aspek berpikir seperti yang diuraikan dalam standar kompetensi, kompetensi dasar, maupun indicator yang terdapat dalam kurikulum. Sedangkan menurut pendapat Sudjana (2012) bahwa penyusunan tes evaluasi perlu memperhatikan dari segi bahasa. Bahasa yang baik dan benar akan memudahkan siswa untuk mengetahui makna yang terkandung dalam rumusan pertanyaan.

\section{c. Keterbacaan Instrumen Asesmen Komprehensif}

Keterbacaan adalah ukuran dari pemahaman siswa terhadap instrumen asesmen komprehensif berbasis kompetensi. Penilaian keterbacaan diwakili oleh tujuh belas siswa. Hasil analisis keterbacaan instrumen asesmen 
komprehensif ditunjukkan pada Gambar 2.

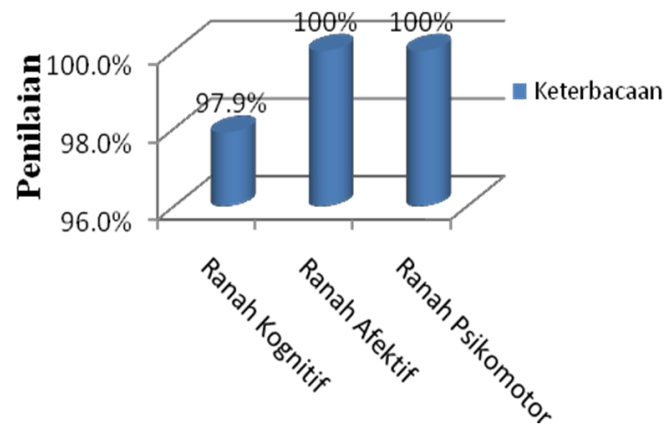

Gambar 2. Hasil Penilaian Keterbacaan Asesmen

Berdasarkan Gambar 2 tersebut, penilaian keter bacaan berdasarkan kesulitan kalimat diperoleh hasil pada ranah kognitif sebesar $97.9 \%$, ranah afektif sebesar $100 \%$, dan ranah psikomotor sebesar 100\%. Hal ini menunjukkan bahwa instrumen asesmen komprehensif berbasis kompetensi yang dikembangkan layak dipergunakan.

\section{d. Kepraktisan Instrumen Asesmen Komprehensif}

Kepraktisan adalah kualitas asesmen dilihat dari keterlaksanaan instrumen asesmen komprehensif. Kepraktisan instrumen diperoleh dari pengamatan keterlaksanaan yang dilakukan oleh empat orang pengamat. Hasil pengamatan keterlaksanaan instrumen asesmen komprehensif berbasis kompetensi berkategori sangat baik. Persentase keterlaksanaan instrumen asesmen komprehensif berbasis kompetensi dan reliabilitasnya masing-masing sebesar $100 \%$ dan 95\%.

Hasil ini menunjukkan bahwa instrumen asesmen komprehensif telah terlaksana dengan sangat baik dan instrumen keterlaksanaan yang digunakan reliabel. Hal ini sesuai seperti dikemukakan oleh Hobri dalam Astuti, dkk (2012), bahwa berdasarkan kriteria kepraktisan bahwa instrumen dikatakan praktis apabila $80 \%$ responden atau lebih memberikan respon positif terhadap instrumen yang dikembangkan.

\section{e. Hasil Uji Coba}

Efektivitas instrument asesmen komprehensif berbasis kompetensi yang dikembangkan mencakup empat analisis asesmen yaitu reliabilitas soal, tingkat kesukaran butir soal, dan sensitivitas butir soal, serta interpretasi hasil asesmen.

Penggunaan karakteristik keempat analisis asesmen tersebut, mengacu kepada analisis asesmen beracuan kriteria/patokan untuk menentukan penguasaan siswa terhadap sejumlah tujuan belajar atau kompetensi (Ibrahim, 2005; Ratumanan dan Laurens, 2011; Suwono, 2011).

Tes beracuan kriteria mengacu kepada suatu criteria pencapaian standar (tujuan) yang telah ditentukan sebelumnya. Nilai-nilai yang diperoleh siswa dihubungkan dengan tingkat pencapaian penguasaan (mastery) siswa tentang materi pengajaran sesuai dengan tujuan (instruksional) yang telah ditetapkan.

\section{Ranah Kognitif}

\section{1.a. Reliabilitas asesmen ranah kognitif}

Hasil perhitungan koefisien reliabilitas asesmen ranah kognitif ditunjukkan pada Tabel 2 berikut ini:

Tabel 2. Hasil Perhitungan Koefisien Reliabilitas Asesmen Ranah Kognitif

\begin{tabular}{|c|l|l|c|c|}
\hline No & $\begin{array}{c}\text { Jenis } \\
\text { Instrumen }\end{array}$ & \multicolumn{1}{|c|}{$\begin{array}{c}\text { Bentuk } \\
\text { Reliabilitas }\end{array}$} & Nilai & $\begin{array}{c}\text { Interpre- } \\
\text { tasi }\end{array}$ \\
\hline 1 & $\begin{array}{l}\text { Tes } \\
\text { objektif }\end{array}$ & $\begin{array}{l}\text { Kuder- } \\
\text { Richardson } 21 \\
(\text { KR-21 })\end{array}$ & 0,39 & Reliabel \\
\hline 2 & $\begin{array}{l}\text { Tes } \\
\text { uraian }\end{array}$ & Alpha $\left(\mathrm{r}_{11}\right)$ & 0,45 & Sedang \\
\hline
\end{tabular}

Jika ditinjau dari hasil perhitungan koefisien reliabilitas asesmen ranah kognitif di atas yang diperoleh relatif rendah. Hal ini sesuai dengan pernyataan yang dikemukakan oleh Suwono (2011) bahwa pada umumnya rentang hasil tes penilaian beracuan kriteria lebih sempit daripada hasil tes beracuan norma, akibatnya koefisien reliabilitas yang diperoleh juga relatif rendah. Gronlund (2003) menyatakan bahwa karena tes beracuan kriteria tidak dirancang untuk membandingkan antar siswa, maka biasanya memiliki skor variabilitas yang terbatas sehingga menghasilkan reliabilitas yang rendah.

Hasil analisis tingkat kesukaran asesmen ranah kognitif ditunjukkan pada Tabel 3 berikut ini:

Tabel 3. Hasil Perhitungan Tingkat Kesukaran Asesmen Ranah Kognitif

\begin{tabular}{|c|l|c|c|c|}
\hline No & Jenis Instrumen & $\begin{array}{c}\text { Jumlah } \\
\text { soal }\end{array}$ & Nilai & Interpretasi \\
\hline 1 & Tes objektif & 11 & $36,7 \%$ & Mudah \\
& & 16 & $53,3 \%$ & Sedang \\
& & 3 & $10 \%$ & sukar \\
\hline 2 & Tes uraian & 2 & $20 \%$ & Mudah \\
& & 4 & $40 \%$ & Sedang \\
& & 4 & $40 \%$ & sukar \\
\hline
\end{tabular}

Jika ditinjau dari hasil perhitungan tingkat kesukaran asesmen ranah kognitif secara umum mempunyai tingkat kesukaran yaitu 1). Mudah; sebanyak 13 soal (32,5\%), 2). Sedang; sebanyak 20 soal (50\%), dan 3). Sukar; sebanyak 7 soal $(17.5 \%)$.

Jika dilihat sebaran hasil perhitungan tingkat kesukaran pada asesmen ranah kognitif terdapat sedikit perbedaan dengan komposisi yang diharapkan dalam asesmen ranah kognitif adalah 3:5:2, maksudnya 30\% soal dengan kategori mudah, 50\% soal dengan kategori 
sedang, dan 20\% soal dengan kategori sukar (Ratumanan dan Laurens, 2011; Sudjana, 2012). Berkaitan dengan perbedaan tersebut, tingkat kesukaran asesmen ranah kognitif relatif proporsional.

\section{1.c. Sensitivitas asesmen ranah kognitif}

Hasil analisis sensitivitas asesmen memperlihatkan bahwa tes objektif mempunyai dua tingkat sensitivitas yaitu 1). sensitif; sebanyak 27 butir soal yang mempunyai indeks sensitivitas $0,3-1(90 \%)$ dan 2$)$. kurang sensitif; sebanyak 3 butir soal yang mempunyai indeks sensitivitas 0,26-0,29 (10\%). Tes uraian mempunyai dua tingkat sensitivitas yaitu 1). sensitif; sebanyak 6 butir soal yang mempunyai indeks sensitivitas $0,38-0,82$ (60\%) dan 2). Kurang sensitif; sebanyak 4 butir soal yang mempunyai indeks sensitivitas 0,12-0,29 (40\%). Butir soal dikatakan sensitif terhadap pembelajaran apabila koefisien sensitivitasnya $\mathrm{S} \geq 0,3$, maka butir soal tersebut peka terhadap efek pembelajaran.

Butir soal yang kurang sensitif menunjukkan bahwa soal yang diberikan oleh peneliti kurang sesuai dengan proses pembelajaran yang diterima siswa di sekolah. Hal ini nampak terlihat dari tingkat pencapaian siswa rendah, sehingga dapat ditafsirkan bahwa proses pembelajaran yang dilaksanakan kurang efektif. Butir soal yang kurang sensitif bisa digunakan karena masih memiliki nilai sensitivitas. Hal ini sebagaimana dikemukakan oleh Gronlund (1977) bahwa sensitivitas butir soal dinyatakan sebagai nilai indeks yang nilainya berkisar antara 0,00 sampai 1,00. Semakin besar indeks sensitivitas, maka semakin sensitif soal tersebut, yang artinya soal dapat memberikan informasi bahwa hasil pengukuran merupakan akibat dari pembelajaran yang dilakukan atau mengukur efek pembelajaran.

Butir-butir soal yang kurang sensitif menandai tingkat pencapaian suatu butir kecil (banyak siswa yang gagal), maka proses pembelajaran kurang efektif. Namun demikian, harus diperhatikan pula kualitas butir tes tersebut secara kualitatif. Jika hasil analisis soal sebelumnya secara kualitatif menunjukkan baik dari segi materi, konstruksi, maupun bahasa, maka butir tes sudah memenuhi syarat.

\section{Ranah Afektif}

Hasil perhitungan reliabilitas asesmen ranah afektif menggunakan rumus Alpha (r11) adalah 0,81, Berdasarkan interpretasi reliabilitas instrumen, maka $\mathrm{r} 11=$ 0,81 dikategorikan memiliki reliabilitas tinggi. Tes tersebut memiliki homogenitas yang baik dan karenanya tes tersebut dikatakan memiliki reliabilitas yang signifikan (Thoha, 2003).

Jika dilihat hasil perhitungan reliabilitas pada asesmen ranah afektif diketahui bahwa reliabilitas tinggi.
Hal ini dimungkinkan disebabkan pada penelitian ini, digunakan metode laporan diri (self assessment) dimana siswa mengisi sendiri angket sesuai karakteristik diri siswa. Relevan dengan apa yang dikemukakan Andersen (dalam Depdiknas, 2008b) metode laporan diri berasumsi bahwa yang mengetahui keadaan afektif seseorang adalah dirinya sendiri. Namun hal ini menuntut kejujuran dalam mengungkap karakteristik afektif diri sendiri.

\section{Ranah Psikomotor}

Hasil perhitungan reliabilitas asesmen ranah psikomotor I (uji sifat asam basa larutan menggunakan indikator yang sesuai) menggunakan rumus Alpha (r11) adalah 0,52. Berdasarkan interpretasi reliabilitas instrumen, maka $\mathrm{r} 11=0,52$ dikategorikan memiliki reliabilitas sedang. Sedangkan hasil perhitungan reliabilitas asesmen ranah psikomotor II (keterampilan menggunakan mikroskop) menggunakan rumus Alpha (r11) adalah 0,62. Berdasarkan interpretasi reliabilitas instrumen, maka $\mathrm{r} 11=0,62$ dikategorikan memiliki reliabilitas sedang.

Jika dilihat dari hasil perhitungan koefisien reliabilitas asesmen ranah psikomotor di atas yang diperoleh relatif sedang. Hal ini sejalan dengan yang dikemukakan oleh Suwono (2011) bahwa penghitungan reliabilitas penilaian beracuan kriteria tidak sama dengan penilaian beracuan norma, karena penilaian beracuan kriteria tidak dimaksudkan untuk memaksimalkan reliabilitas.

Selama proses pembelajaran, siswa telah diberikan penjelasan baik melalui demonstrasi maupun praktikum sehingga mudah memahami tentang keterampilan ranah psikomotor yang diujikan. Hal ini sesuai dengan penelitian Duda (2010) terlihat bahwa pembelajaran berbasis praktikum berhasil menciptakan suasana kondusif sehingga secara keseluruhan siswa efektif dalam belajar.

\section{SIMPULAN}

Berdasarkan hasil dan pembahasan dapat disimpulkan bahwa bentuk dan karakteristik instrumen asesmen komprehensif berbasis kompetensi pada mata pelajaran IPA/Biologi yang dikembangkan valid, praktis, dan efektif. Instrumen asesmen komprehensif berbasis kompetensi layak digunakan sebagai alat ukur pencapaian kompetensi dasar dan instrumen yang digunakan reliabel.

\section{Daftar Pustaka}

Arikunto, S. 2013. Dasar-Dasar Evaluasi Pendidikan. Edisi 2. Jakarta: Bumi Aksara.

Astuti, W. P., Prasetyo, A. P. B., dan Rahayu, E. S. 2012. "Pengembangan Instrumen Asesmen Autentik Berbasis Literasi Sains Pada Materi Sistem Ekresi”. 
Jurnal Lembaran Ilmu Kependidikan. Vol. 41 No. 1, pp. 39-43.

Depdiknas. 2008a. Rancangan Penilaian Hasil Belajar. Jakarta: Direktorat Pembinaan Sekolah Menengah Atas, Direktorat Jenderal Pendidikan Dasar dan Menengah, Departemen Pendidikan Nasional.

Depdiknas. 2008b. Pengembangan Perangkat Penilaian Afektif. Jakarta: Direktorat Pembinaan Sekolah Menengah Atas, Direktorat Jenderal Manajemen Pendidikan Dasar dan Menengah, Departemen Pendidikan Nasional.

Duda, H.J. 2010. "Pembelajaran Berbasis Praktikum dan Asesmennya pada Konsep Sistem Ekskresi untuk Meningkatkan Kemampuan Berpikir Kritis Siswa Kelas XI". Jurnal VOX Edukasi. Vol.1 No.2 Juli 2010, pp. 29-39.

Gronlund, N. E. 1977. Constructing Achievement Tests. Second Edition. New Jersey: Prentice Hall.

Gronlund, N. E. 2003. Assessment of Student Achievement. Seven Edition. Boston: Allyn and Bacon.

Hairida. 2011. "Asesmen Otentik : Menghadapi Era Globalisasi (Menjawab Tantangan Internal dan Eksternal Pendidikan)". Jurnal Visi Ilmu Pendidikan. Vol. 5 No.2, pp. 417-431.

Ibrahim, Muslimin. 2005. Asesmen Berkelanjutan. Konsep dasar, tahapan pengembangan dan contoh. Surabaya: Unesa University Press.

Muslich, Masnur. 2010. Authentic Assessment: Penilaian

Berbasis Kelas dan Kompetensi. Bandung: Refika Aditama.

Ratumanan, T. G. dan Theresia L. 2011. Penilaian Hasil Belajar pada Tingkat Satuan Pendidikan Edisi 2. Surabaya: Unesa University Press.

Slavin, R.E., 2009. Psikologi Pendidikan: Teori dan Praktik, Edisi Kedelapan, Jilid 2. Jakarta: PT Indeks.

Sudjana, Nana. 2012. Penilaian Hasil Proses Belajar Mengajar. Bandung: PT Remaja Rosdakarya.

Surapranata, Sumarna. 2005. Analisis, Validitas, Reliabilitas dan Interpretasi Hasil Tes Implementasi Kurikulum 2004. Bandung: PT Remaja Rosdakarya.

Suwono, Hadi. 2011. Panduan Pengembangan Penilaian Mata Pelajaran Biologi. Malang: Workshop Subject Specific Pedagogy. Pendidikan Profesi Guru Universitas Negeri Malang.

Thiagarajan, S., Semmel, D. S., and Semmel, M. L. 1974. Instructional Development for Training Teachers of Exceptional Children: A Sourcebook. Minneapolis, Minnesota: USOE Publication.

Thoha, M. C. 2003. Teknik Evaluasi Pendidikan. Jakarta: PT. Raja Grafindo Persada.
Wiggins, G. 1993. Assessing Student Performances. San Francisco: Jossey-Bass Publisher. 